\title{
Effectiveness Analysis of Agricultural Protection Policy on Food Supply, Export and Farmer-Welfare in Nigeria: Generalized Method of Moment Approach
}

\author{
Mr. Emmanuel Ejiofor Omeje \\ University of Nigeria Nsukka, Faculty of Agriculture, Department of Agricultural Economics, Nsukka, Enugu State, \\ Nigeria. ejiofor.omeje@unn.edu.ng, Phone 08038090907 \\ Prof. Chukwuemeka John Arene \\ University of Nigeria Nsukka, Faculty of Agriculture, Department of Agricultural Economics, Nsukka, Enugu State, \\ Nigeria. cjarene@yahoo.com \\ Dr. Benjamin Chiedozie Okpukpara \\ University of Nigeria Nsukka, Faculty of Agriculture, Department of Agricultural Economics, Nsukka, Enugu State,
} Nigeria. Benjamin.okpukpara@unn.edu.ng

Received: November 9, 2018

Accepted: November 13, 2018

Online Published: November 17, 2018

\begin{abstract}
This study examined the effectiveness of agricultural protection policy and other macroeconomic variables on food supply, agricultural export, and farmers welfare in Nigeria, from 1980-2016 with a special interest in their relationship with the political economy. The specific objectives were to (i) estimate the degrees of agricultural protection, domestic agricultural food supply and economic welfare to farmers in Nigeria, (ii) determine the effectiveness of agricultural protection on food self-supply, agricultural export; and farmer-welfare. Data were obtained from secondary sources. Descriptive statistics and generalized method of moment (GMM) were used. Nigeria's self-food supply was slightly above $50 \%$ while the rest of the consumption depended on importation. The welfare measure to farmers was relatively poor and not good enough to motivate them. There was a positive and significant relationship between export and agricultural protection. A significant and positive relationship also exists between farmer-welfare and protection in the sector.
\end{abstract}

Keywords: Agricultural protection, effectiveness, self-food supply, agricultural export, farmer-welfare, generalized method of moment.

\section{Introduction}

Agriculture has been a major source of income for many Nigerian people, source of export earnings by the government and source of own food for its growing population. According to Okumadewa, (1997), agriculture contributes immensely to Nigeria's economy in various ways including provision of food for the increasing population, supply of adequate raw materials (and labour input) to the growing industrial sector, a major source of employment; generation of foreign exchange earnings, and, provision of market for the products of the agrarian sector. Asirvatham (2016) opined that agricultural protection represents an effort by the political class to increase agricultural growth by improving national food security and minimizing food dependence on foreign countries. This means that the agricultural sector has a strong relationship with the economy and hence, the concern for agricultural policies. 
In economic and political terms, agricultural protection policies are not new in Africa. According to the Organisation for Economic Co-operation and Development [OECD] (2018), agricultural protection could be defined as the ratio between the average price received by producers (measured at the farm gate), including net payments per unit of current output, and the border price (measured at the farm gate). For instance, a coefficient of 1.10 suggests that farmers, overall, received prices that were $10 \%$ above international market levels. This indicator reflects the level of price distortions and is measured by the Producer Nominal Protection Coefficient expressed as the ratio of farm price to border reference price. Also, any policy that puts up tariffs or other trade barriers on agricultural products so as to prevent or discourage imports or any policy that seeks to promote agriculture in a given area is termed agricultural protection policy.

The patterns of agricultural protection policies in Africa suggest that developing nations strongly subsidize agriculture (Olper, 1998). Other scholars like Inhwam (2008) and Barrette (1999) had argued that agricultural protection is capable of creating negative externalities to developing countries because agricultural protection distorts trades of agricultural products which some developing countries have a comparative advantage in producing. Goldin and Knudsen (1990) opined that since agriculture is a sector of comparative advantage for many developing countries now and for some time in future, agricultural protection does not materially impair their potentials for economic growth. Swinnem (1996), Inhwam, (2008) and Barrett (1999) noted that some political environment surrounding food price policy differs markedly across time in a given country and cross-sectional among countries at any given time.

The political economy of financing and or supporting agricultural policy by the government is determined by the government's interests. To determine where, when or how much resources any rational government would commit into agricultural protection, some important political economy factors or indicators are expected to guide the decision. Bratton and van de Walle (1994) viewed political economy variables as those factors taken into consideration as economic and political exigencies when analyzing determinants of protectionism. Such political economy variables may include the state of food security or food self-sufficiency status; the contribution of foreign exchange earnings from the sector's export; general economic welfare to farm producers; GDP of the sector; policy changes; budgetary allocation to the sector; and political or structural changes in the economy. In the same line of thought, Amin (1972) explained that the different regimes reflected varying economic and political interests and similar commodity biases. It is expected that a nation whose food supply is grossly dependent on import would be politically vulnerable. Food production during the World Wars generated the revenues necessary for administrative independence for some countries (Cooper, 2002). Pejout opined that food riots and violence became more prevalent in African cities following the rapid escalation of food prices in 2008 (Pejout, 2010) and this resulted in political instability and drove governments to re-analyze their agricultural policy. General economic welfare to farmers is also a political indicator that determines the demand push for protection from voters/farmers. It is expected that when the farmers are not making much of profit, their demand for protection may likely increase. Sometimes, it is suspected that political class purposively increases the budget for protection or subsidies in order to gain political support during elections. In line with this, Bratton and van de Walle (1994), opined that political class or elite mobilize political support by using their public position to distribute rent-seeking opportunities such as subsidies, interest free-loan, or grants. Nations' GDP or GNP appears to be a quick tool in the hands of politicians for measuring the progress of policies. The GDP situation during a specific period or policy regime may guide the political class on whether more funds should be pushed into the sector or not. Also, the government usually would like to increase revenue through agricultural export since financial constraints can weaken administrative capacity and threaten political stability (Gardner, 2012).

Governments' decision to intervene and finance agricultural sector is usually spurred by a number of factors but common among them is to protect the farmers' commodity price from domestic and international market forces; to improve farmers' income and standard of living; and to protect the consumers from excessive prices (Inhwam, 2008). Therefore, agricultural projects and policy reforms are expected to be subjected to analyses to examine its effectiveness in ensuring production of own food, increasing export and improving the wellbeing of the producers. Problem statement 
It is notable that between 1980 and 2016, the federal government of Nigeria has promulgated various agricultural policies and implemented many projects and programmes with the views to improving the standard of livelihood of producers, increase food supply and agricultural export. For example, in 1981, Nigeria pursued import substitution industrialization strategy of which import prohibition policy was pronounced; from 1981, the policy shifted towards export promotion policy. At this point, the government was made to embark on the Economic Stabilization Policy (temporal provisions) act in April 1982.

To consolidate the policy, Nigeria further protected agriculture sector when the policy brought about the prohibition of frozen poultry while tariff on 49 agricultural commodities was raised. Between 1983 - 1985, 152 items were brought specific import license and foreign exchange policy regulations became more stringent (Briggs, 2007). In 1986, a noticeable shift in policy was directly attributed to greater liberalization policy and the adoption of structural adjustment programme (SAP). Between 1988 and 1994, protection policy became more evident when the government provided a seven-year import tariff where imports attracted ad valorem rates applied in Most Favoured Nation (MFN) basis. Also, between 1995 and 2001, another tariff regime succeeded in the previous regime.

The restructuring and recapitalization of the Nigeria Agricultural Bank to provide loans to peasant farmers at single digit interest rates. The launching of the Growth Enhancement Scheme to cater for farmers using the E-wallet system. The substitution of $20 \%$ of wheat bread flour with cassava flour. Agricultural commodity marketing and pricing policy in 1977, six national commodity boards were established which include; commodity boards for cocoa, groundnuts, palm produce, cotton, rubber and food grains. Land use policy was promulgated by the Federal Government in 1978 vesting the ownership of all lands on the government as to giving genuine farmers access to farmlands. Agricultural extension and technology transfer policy aimed at improving the adoption of improved agricultural technology by farmers with the National Accelerated Food Production Project (NAFPP) and agricultural development projects (ADPs) as implementing agencies. Input supply and distribution policy were promulgated to ensure adequate and orderly supply of agricultural inputs notably fertilizers, agrochemicals, seeds, machinery and equipment such that agricultural input subsidy policy on fertilizer was 50\%, agro-chemicals (50\%) and tractor hiring services $(50 \%)$.

Also, agricultural research policy was established in 1971, followed by Agricultural co-operatives policy in 1979 and water resources and irrigation policy which brought about the establishment of eleven River Basin Development Authorities in 1977 charged with the responsibility of developing Nigeria's lands and water resources and Agricultural mechanization policy which was instrumental to the creation of the Ministry of Science and Technology and the establishment of some Universities of Science and Technology, the operation of tractor hiring units in all the states of Nigeria, reduced import duty on tractors and agricultural equipment and implements, generalized and liberalized subsidies on farm clearing and establishment of a centre for agricultural mechanization. Despite all these efforts, poverty has persisted in the sector where over $70 \%$ of its rural population is engaged in agricultural activities (International Food and Agricultural Development [IFAD] 2016, National Bureau of Statistics, [NBS], 2017). According to Olawepo (2010), income has generally remained low from agricultural production in Nigeria. Also, International Fund for Agricultural Development (IFAD, 2016; NBS, 2017) reported that despite all these many efforts, poverty is still widespread in the country and has been on increase since the 1990s. Also, past studies have shown that most of these poorest households are found working in agriculture (Ikpi, 1989; Ayoola, Aina, Mamma, Nweze, Odebiyi, Okumadewa, Shehu, Williams \& Zasha, 2000; Alayande \& Alayande, 2004; Poulton, Doward \& Kydd, 2005). Prices are also not stable as agricultural commodities were hit with inflation of about $18.72 \%$ in January 2017, one of the highest in the history of Nigeria (National Bureau of Statistics (NBS, 2017). For this suspected paradox of multiple protection policies with stagnated policy outcomes, there is an urgent need for a proper assessment of the effectiveness of agricultural protection policy since all these protectionist interventions may have not yielded the much-expected results in Nigeria. The objective of this research was to empirically evaluate the effectiveness of agricultural protection policies, programmes and projects on the general economy with a special interest in domestic food supply, export and producer welfare. 


\section{Literature Review}

\subsection{Effects of Agricultural Protection in the Economy}

In Olatomide and Omowumi (2013), the assessment of the effects of the agricultural support reforms and policies on the agricultural sector is with respect to the fundamental roles of agriculture which include provision of adequate food for a growing population and raw materials for industries, provision of an expanding market for nonagricultural products, generation of savings for investment in agriculture as well as other sectors and release of surplus or underutilized resources to other sectors, and generation of foreign exchange.

Joachim and Valdes (1993) are of the view that Agricultural protectionism in industrialized countries is well known to heavily burden consumers and/or taxpayers but it also reaches far beyond a country's borders. It negatively affects actual or potential agricultural exporters. On the contrary, Abou and Takor in 2003 conducted a study on "the Relevance of Tax Incentives in Export-oriented Enterprises in Lebanon". 117 managers of export businesses in Lebanon were considered for the study to indicate whether tax incentives significantly promote their investment. The data generated from the study, which were analyzed using simple percentages, revealed that a tax incentive is a strong tool for investment promotion in export-oriented businesses like agriculture. Similarly, Gomes (1999) conducted a pilot study of twenty-five (25) business executives and his findings indicated several forms of tax incentives applicable to businesses in Brazil.

Holland (1996) conducted a study on "Income tax incentives for investment in agro-allied business" and the researcher operationalized tax incentive into investment allowance and loss relief. The main objective of that study was to examine the extent to which tax incentives influence the investment of agro-allied business in free-trade zone areas. In order to collect the necessary data for the study, Holland considered eighty-three business executives whose businesses are located in the nine free-trade zones in Uruguay. Part of her findings showed that investment allowance and loss relief has a positive significant impact on corporate investment of agro-allied businesses.

According to Philip (1995), the tax incentive is a deliberate reduction in or total elimination of tax liability granted by the government in order to encourage particular economic units to act in some desirable ways-invest more, produce more, employ more, save more, consume less, import less, pollute less and so on.

From the political point of view, agricultural protection could be a tool for gathering voters' support. Public choice and collective action theories hypothesize that the interests of politicians, bureaucrats, and farm organizations are the driving forces increasing government protection (Swinnen \& van Der Zee, 1993; Josling et al, 2010). Supporting this view, Gardner (1994) suggests that the nature of agricultural protectionism has shifted from problem-solving to interest-group politics.

Gardner (1987) had earlier examined why the extent of government intervention differs from commodities in the US. The study showed that self-sufficiency rates in agricultural products were negatively related to the protection rates: i.e. if the commodity faces import competition, it is likely to receive greater protection. Low elasticity of demand and supply was positively associated with it. The share of the commodity in aggregate agricultural output had a positive effect on the protection. In addition, Swinnen (1994) highlighted the role of relative farm incomes and the countercyclical nature of agricultural protection. After controlling for the effects of economic development, terms of trade, comparative advantages, and constraints on tax collection feasibility, Beghin and Kherallah (1993) showed that agricultural protection level increases as the political system moves to a more pluralistic form. Yet, the study showed that further transition to democratization causes partial dissipation of protection and agricultural protection may persist if transactions costs in connection with eliminating/reducing farm programs/policies are substantial. In line with this importance of the political system, Thies and Porche (2005) examined political institutional factors on a more detailed level and showed that veto players, federalism, party fragmentation and the timing of elections are as important as other economic factors. 


\subsection{The System of Protectionism in Agriculture}

According to Akanegbu (2015), Protection can be given through tariffs - taxing particular imports but not locally produced versions of the same product or through quantitative restrictions on imports, such as quotas or outright embargoes, limiting the imported supply, or through both together. However, a major disadvantage of the widespread use of protection is that it discourages and decreases trade, thereby, destroying or giving up many of the advantages from trade. There is overwhelming empirical evidence that suggests a strong link between price distortions and economic growth, especially in developing countries; Harberger (1959) attempted to explore the possible results of eliminating misallocations of resources in economies like Chile, Brazil, and Argentina. It was concluded that policies aimed at eliminating distortions in the price mechanism can raise the long-term rate of growth of national income.

Also, results from global and single country studies of subsidy reform suggest that on an aggregate level, changes to GDP are likely to be positive due to the incentives resulting from price changes leading to more efficient resource allocation (Von Moltke, Mckee, \& Morgan, 2004). Also, there is evidence that tax policy has influenced the pattern of investment with consequent effects on overall efficiency. Lower taxes have resulted in higher real returns to savings and then investments. Higher returns have stimulated a larger aggregate supply of these factors of production and thus raised total output. Also, in low-tax countries, different types of financial incentives that were provided appear to have shifted resources from less productive to more productive sectors and activities, thus increasing the overall efficiency of resources utilization.

Some analysts have attempted to estimate the costs of protection in models using general equilibrium methods to examine the general effects of trade liberalization. For example, De Melo (1978), in his study, divided the loss of real income due to protection into two elements: (a) the consumption costs resulting from the distorted prices facing consumers as domestic prices differ from world prices, and (b) the production costs resulting from distortions of prices facing producers. Therefore, the total cost of protection is measured by the total reduction in utility from the above effects. However, a general equilibrium approach was used which is not restricted to small departures from free trade. The analysis is based on a Walrasian approach, which emphasizes the importance of substitution effects in both product and factor markets on the grounds that a removal of trade barriers entails a large change in relative prices that is likely to affect both producer's and consumer's choices.

More so, protection has a joint effect of being a consumption tax and a production subsidy, and it reduces the utility enjoyed by the community both by reducing real output below the maximum attainable from the expenditure of the real output below the potential maximum. It was noted that removing quota alone in Turkey in 1978 would have increased its GDP by as much as 5.4\% (Grais, De Melo \& Urata, 1986). Also, Ubogu (1988) conclude that a liberal trade regime with low tariffs and without quotas up to 1973 led to export-led growth in the world economy and relative stability in Nigeria's export earnings and inflow of foreign capital.

Also, further study by the World Bank monitored agricultural support policies in transition economies (World Bank, 2000). This study covers six transition economies during the period 1994-97. Using a direct price comparison approach, the study presents various estimates of agricultural support policies including trade and price policy interventions and government non-price related subsidies on production incentives and on net farm income. The study examined to what extent the economic environment prevailing in 1994-97 provided an appropriate and sound basis for adjustment towards a more internationally competitive agricultural sector. Based on a common methodology for all countries, the study reports estimates of NPR, ERP, and ERA for the major agricultural importcompeting and export activities. The report presents a synthesis of the various indicators for all the countries included, which is followed by individual country agricultural policy notes describing the salient features of agricultural policies at the time. This study does not adjust for a possible misalignment of the exchange rate, though it does present a "decomposition analysis" to examine the relative effect of fluctuations in the real exchange rate, border prices and domestic trade policy on the evolution of domestic real farm prices. 
In addition to those studies mentioned above, Josling and Valdes (2004) noted that the on-going FAO study on the roles of agriculture includes a component on agricultural support measures. The study includes a total of 11 countries in Asia, sub-Saharan Africa, North Africa and Latin America. The analysis presents estimates of nominal and effective rates of protection for the late 1990s, for the major agricultural import-competing and export activities (approximately six activities in total).

In summary, the patterns of agricultural protection vary among countries. The political market framework of protection provides factual evidence to show that producers in industrialized countries such as Australia, Canada, Japan, United States, etc. are subsidized while the low-income countries such as China, Pakistan, India, Turkey, Bangladesh, Argentina, etc. tax the farmers. Also, an analysis of the evolution of producer prices shows that between 1986 and 1995, in seven out of eight countries, all major agricultural producer prices declined in real terms in which most countries, the decline for both import and export was larger during the reform period than in the previous years.

At the root of everything in an economy is the force of demand and supply. It is not farfetched to think of these as basically human characteristics. In this context, the government or the ruling class represents the supply side while the consumers or farmers represent the demand side of agricultural protectionism (Zietz \& Valdes, 1993). Downs's (1957) neoclassical economic theory of politics provides a simple starting point. The model allows one to think of protection as the result of demand and supply forces. Downs's model assumes that politicians adopt policies that maximize their chances of staying in office. The beneficiaries of a particular policy, such as government assistance, invest in lobbying effort up to the point where an additional investment of resources is expected to have no net benefits (Baldwin 1982). Baldwin added that the expected losers of a particular policy also invest in lobbying effort, similarly balancing marginal cost and expected marginal benefit. Since one can think of the beneficiaries of government assistance as on the demand side for protection, whereas politicians are on the supply side. Politicians supply protection up to the point where the marginal cost of lost support from those opposing government assistance or protection is just equal to the marginal gain in support from those groups demanding assistance or protection.

Zietz and Valdes (1993) explain that the emphasis of Downs's model on marginal changes clearly entails one problem: it is ill-equipped to deal with large changes, such as major structural shifts or regime switches. In those instances, political coalitions tend to break down or are realigned, and formal models based on marginal changes can, therefore, predict little. However, the loss of comparative advantage in agriculture tends to occur gradually rather than at distinct points in time. Hence, sufficient political stability may be maintained, at least in principle, even though not in each case, for Downs's model to remain a useful framework for thinking about the growth of agricultural protection.

From the earlier discussion, it followed that the basic demand of farmers for protection or, more generally, government intervention results from the high cost, relative to investing in political lobbying, of avoiding income losses through raising productivity growth; diversifying into products with high-income elasticity; or more off-farm employment. According to Downs's theory and Olson's (1965) work, the demand for protection gains political clout with a decline in group size and the consequent cost of the organization.

The empirical work by Honma and Hayami (1986) has provided support for this hypothesis for agriculture that as agriculture shrinks in the development process, the demand for protection becomes more effective ceteris paribus, reaches a maximum, and eventually declines again as the size of the agricultural sector shrinks under a critical level. In addition to smaller group size, there are other changes taking place as employment shrinks in agriculture that help organize a farming lobby and that raises the demand for government support. Education levels rise and as information and transportation become more easily accessible, better and lower-cost communication links are established with the city centers. According to Zietz and Valdes (1993), the lower cost of information, in turn, allows the rural sector to identify more quickly and more reliably any emerging income disparity in relation to other groups in the country. It also reduces the cost of becoming informed and taking part in and organizing political 
activity. In addition, as agriculture becomes more commercialized, agricultural support services establish themselves in the rural sector.

In general, Arene (2008) notes that supply could be affected by changes in input prices, changes in profitability of substitute commodities, changes in technology, and prices of joint products. Zietz and Valdes (1993), specify that the supply of protection depends on the perceived costs of protection to individuals or groups inside or outside the sector and; the power of the bureaucracy that is charged with overseeing the particular sector demanding protection. Zietz and Valdes (1993) opine that high perceived costs of protection are likely to generate resistance or countervailing power. For politicians, this is equivalent to a rise in their supply curve of protection. Higher bribes are required from the sector seeking protection, while less protection is provided at the same time. Zietz and Valdes further identify a number of factors that tend to shift the supply curve for agricultural protection or support.

i. An agricultural sector that is large relative to other sectors tends to raise the supply curve for agricultural support measures, in particular, income transfers. To provide support to agriculture under this scenario, politicians would have to impose heavy costs on the sectors outside of agriculture. This has been done, for example, in Indonesia starting in the 1970s (Barichello, 1989).

ii. As income increases, food items take up an increasingly smaller budget much of an incentive to get informed or organized to oppose agricultural protection. The costs associated with becoming active are simply much higher than the expected benefits.

iii. Industry resistance to agricultural protection has the potential to shift up the supply curve for protection.

iv. In the long run, as income levels reach a certain critical level, resistance to agricultural protection may also arise out of environmental concerns of the public.

v.Resistance against agricultural protection may also arise from within agriculture itself. Two factors that have already been mentioned separately combine to bring this about. First, agricultural protection raises land prices, that is, the return to the fixed factor. Second, more land is needed by farmers to achieve economies of scale for such land-intensive products as cereals. In sum, agricultural protection actually makes it more difficult for farmers to halt the decline in comparative advantage.

vi.A tight government budget is likely to shift upward the supply curve of protection. This is particularly true if agricultural protection is provided in the form of support prices, as for many commodities in the EC, or when government support of the agricultural sector is provided mainly through budgetary expenses, as in the United States. Its importance can be measured by the fact that it is generally credited with being one of the driving forces behind the Uruguay Round and its focus on agriculture (Zietz \& Valdes 1988).

vii.Protection can be contained by credible pressure from outside the country. This point has already been touched on in the context of industry resistance to agricultural protection. Outside pressure can take the form of bilateral pressure applied by a powerful trading partner that is negatively affected by agricultural support programs or legal obligations such as those driven from General Agreement on Tariff and Trade (GATT).

In summary, the relationship between agricultural protection and demand and supply first, characterized the subject into two basic concepts. The demand side (farmers or consumers) and the supply side (government in power). To supply protection, it has economic consequences - forgone alternative. Despite this, those in power or politicians supply protection up to the point where the marginal loss in support from those opposing government assistance or protection is just equal to the marginal gain in support from those groups demanding assistance or protection. The supply of protection depends on input price, profitability in the sector, change in technology, perceived cost of the protection, groups within and outside the economy.

\section{Methodology}

\subsection{The Study Area}

The study area is officially known as the Federal Republic of Nigeria, but here often referred to as Nigeria. The major exports of the country are: crude oil (petroleum), natural gas, cashew nuts, skin and fur, tobacco, cocoa, 
cassava, rubber, food, live animals, aluminium alloys and other solid minerals, (CIA World Factbook 2018) while major imports are refined petroleum products, wheat, rice, sugar, herbicides, fertilizers, chemicals, vehicles, aircraft parts, vessels, vegetable products, processed food, beverages, spirits and vinegar, equipment, machines, and tools (NBS 2015). Despite its considerable agricultural resources, Nigeria is still a net importer of food and agricultural products in general (USAID 2009) and as such the agricultural sector has been one of the least attractive sectors (Owutuamor and Arene, 2018) and has lost its leading contribution to Nigeria's GDP (CBN 2018; FAO 2012).

\subsection{Data Specification}

This work made use of secondary data. The annual time series data of agricultural output, measured by the share of agriculture to GDP, and FDI inflows into the sector were collected from CBN, spanning from 1980-2015 while 2016 was extrapolated. Also, NPC was calculated from annual data of domestic price collected from FAOSTAT and World price collected from the World Bank. This study covering a 37-year period, spanning from 1980 to 2016 employed descriptive statistics aided by the use of Microsoft Excel and inferential statistics in the form of the econometric regression methods of the multiple linear regression and Granger causality test were applied as the estimation technique in evaluating the relationships and causality between the dependent variable (agricultural growth) and the political economy variables (agricultural protection level, foreign direct investment inflows to agriculture, Gross Domestic Product (GDP) inflows from the agricultural sector into the economy, political structure changes in national policy reforms and form of government in power).

The regression equation was estimated after carrying out pre-estimation tests for stationarity in order to avoid multicollinearity of explanatory variables. To eliminate the presence of autocorrelation in the model, this study applied the Augmented Dickey-Fuller (ADF) test to detect the stationarity of the variables at the 5\% level of significance and also identify the order of integration of the variables in the model. The study was initially designed to be approached with ordinary least square method but due to endogeneity found in the model, instrument variable (IV) generalised method of moment (GMM) was adopted to take care of the endogeneity.

The level of protection in agriculture was estimated using the nominal protection coefficient (NPC) model, level of economic welfare was measured using trade measure (TM), and domestic own food production was estimated using food self-sufficiency ratio (SRR). The effectiveness model was analysed using the generalised method of moment (GMM) with Eviews 9.0 software.

\subsection{Model specification}

The coefficients of the protection level in the agricultural sector are widely estimated using the nominal protection coefficient (NPC). According to De Gorter and Tsur, (1991), Krueger, Schiff, and Valdés, (1991), the most simple and widely used measurement of the price wedge is the nominal rate of protection (NRP) and the nominal protection coefficient (NPC) (Krueger, Schiff and Valdés, 1991; Miller \& Anderson, 1992 and Arene, 2008). The level of protection estimation equation is given as:

$\mathrm{NPC}=\mathrm{P}_{\mathrm{D}} / \mathrm{P}_{\mathrm{W}}$

eq1.

Where:

$\mathrm{P}_{\mathrm{D}}=$ Domestic Producer Price (Naira);

$\mathrm{P}_{\mathrm{W}}=$ World price (Naira).

The coefficient of estimation of Nigeria's own food production was estimated using trade measure (TM) tools. Trade measure is a tool used to evaluate the economic welfare accrued to producers in relation to international prices in a given sector like agriculture. This measurement standard was also adopted as standard procedure on national policies' evaluation and agricultural trade (OECD, 1987). This measurement concept was based on the general phenomenon that a fall in price will lead to fall in farmers' economic welfare. This fall in real farm prices is expected to lead to increased political pressure by farmers as their demand for protection of import-competing subsectors increases (Josling \& Valdes, 2004). 
The trade measure model for Producers adopted in this study is given as:

$\mathrm{TM}=(\mathrm{PD}-\mathrm{PW}) \times \mathrm{DP}$.

eq2.

Where:

$\mathrm{TM}=$ Trade Measure in Agriculture

$\mathrm{PD}=$ Domestic Price

$\mathrm{PW}=$ World price and

$\mathrm{DP}=$ Domestic Production .

The effectiveness of agricultural protection on some growth indicators such as own food production (SSR), agricultural export and farmers welfare (TM) was analyzed in the standard growth accounting framework. The relationship between growth and other macroeconomic variables such as agricultural growth is often analyzed using the standard models of economic growth (Owutuamor and Arene, 2018), we apply the Solow (1956) growth model in which the growth of economies is broken down into basics in the production function:

$Y=f(K, \mathrm{~L})$

eq3.

To account for time factor in the model and adopt equation 1 to the study according to Mankiw, Romer and Weil (1992), adopting the Cobb Douglas model, we make the indicators of effectiveness i.e., domestic agricultural food supply (SSR), agricultural export (AE) and farmer-welfare (FM) functions of NPC and related independent variables at time $(t)$. That is:

$Y 1_{\text {, }}$ or $Y 2$, or $Y 3=f\left(X_{1}, X_{2}, X_{3}, X_{4,} \ldots X_{\mathbb{N}_{2}}\right)$

eq4.

Where: $Y=$ output indicators or measures of effectiveness and $X_{1}, X_{2}, X_{3}, X_{4} \ldots X_{n_{p}}=$ NPC and other factors that determine the rate of output. To account for time factor in the model, according to Mankiw, Romer and Weil (1992), the model is estimated at time $(t)$.

$Y_{\mathrm{t}}=f\left(X_{1(t)} \cdot X_{2(t)} \cdot X_{a(t)} \cdot X_{4(t)} \ldots X_{n(t)}\right)$

eq5.

Assuming there is a steady state, say a linear relationship, as seen in standard output models; output is estimated by multiple linear equations in the linear form in Eq. 3, which formed the basis for the estimation of the model in this study. This study is also based on the assumption that there may be other influential factors affecting growth but this study is only restricted to political economy variables as indicators for quick and easy policy considerations. In order to establish the mathematical function of this model, the intercept $\beta_{0}$, measure of error term $\varepsilon$ and parameters of estimations $\beta_{1,2,3 \ldots n}$ are added in equation 5 .

$Y_{t}=\beta_{0}+\beta_{1} X_{1(t)}+\beta_{2} X_{2(t)}+\beta_{3} X_{3(t)}+\beta_{4} X_{4(t)}+\ldots \beta_{n} X_{n(t)}+\varepsilon$

eq5.

Following this, the GMM model used here followed the same econometric derivatives from equations 3 to 5 thereby giving the GMM econometric models as equations 6,7 and 8.

$\ln \mathrm{SSRFOODR}_{(\mathrm{t})}=\beta_{0}+\beta_{1} \ln \mathrm{FDIAGR}_{(\mathrm{t})}+\beta_{2} \ln \mathrm{TMGR}_{\mathrm{t})}+\beta_{3} \ln \mathrm{POCH}_{(\mathrm{t})}+\beta_{4} \ln \mathrm{BUDAGR}_{(\mathrm{t})}+\beta_{5}$ $\ln \mathrm{CPI}_{(\mathrm{t})}+\beta_{6} \ln \mathrm{NPC}_{(\mathrm{t})}+\beta_{7} \ln \mathrm{INTRATE}_{(\mathrm{t})}+\varepsilon$

$\ln \mathrm{AGREXP}_{(\mathrm{t})}=\beta_{0}+\beta_{1} \ln \operatorname{FDIAGR}_{(\mathrm{t})}+\beta_{2} \ln \mathrm{INTRATE}_{(\mathrm{t})}+\beta_{3} \ln \mathrm{POCH}_{(\mathrm{t})}+\beta_{4} \ln \mathrm{BUDAGR}_{(\mathrm{t})}+\beta_{5}$ $+\ln \mathrm{CPI}_{(\mathrm{t})}+\beta_{6} \ln \mathrm{NPC}_{(\mathrm{t})}+\beta_{7} \ln \mathrm{TMGR}_{(\mathrm{t})}+\beta_{8} \ln \mathrm{EXRATE}_{(\mathrm{t})}+\varepsilon$

$\ln \mathrm{TMGR}_{(\mathrm{t})}=\beta_{0}+\beta_{1} \ln \mathrm{EXRATE}_{(\mathrm{t})}+\beta_{2} \ln +\beta_{3} \ln \mathrm{BUDAGR}_{(\mathrm{t})}+\beta_{4} \ln \mathrm{NPR}_{(\mathrm{t})}+\beta_{5} \ln \mathrm{GOTYPE}_{(\mathrm{t})}+\beta_{6} \ln \mathrm{C}$ $\mathrm{PI}_{(\mathrm{t})}+\beta_{7} \ln \mathrm{POCH}_{(\mathrm{t})}+\ln \beta_{7} \mathrm{AGREXP}_{(\mathrm{t})}+\varepsilon$

eq6.

eq7.

Where: GDP = agricultural GDP (GDP percentage share to agricultural sector is an indicator tool for making quick

eq8. adjustments in the economy),

$\mathrm{EXR}=$ exchange rate in percentage,

NPC = nominal protection coefficient (used as proxy for measuring the degree of agricultural protection),

SSR = national food situation of political economy (SSR was modeled to capture the dependency ratio of Nigeria's own food production),

FDIAGR = Foreign Direct Investment (FDI percentage share to agricultural sectors represents the economic and political will of individuals to invest in the sector),

INTRATE = Interest rate in percentage,

EXTDEBT $=$ external debt in percentage and

$\mathrm{CPI}=$ consumer price index as a general measure of effect of price on protection dynamics. 


\section{Results and Discussion}

\subsection{Pre-Estimation Techniques}

Some form of data modification and pre-estimation processes were carried out before the main analyses were conducted. The set of data was tested for a unit root in the study. ADF was used to carry out the test under its traditional conditions, hypotheses and decision rules as adopted by Nwosu and Okafor (2014). In a related study, Njoku, Chigbu and Akujobi (2015) also adopted the use of unit root test on some residuals using the ADF test. The variables were further tested for endogeneity and corrections made. Also, the variables were further subjected to cointegration test to check for a long-term association.

The decision rule showed that the prob (t-stat) $>0.05$ which implied that the null hypothesis of no integration be rejected and we, therefore, concluded that the variables in the model have a long-term relationship. The results of the $\mathrm{ADF}$ and co-integration tests are shown in Tables 1 and 2 . The result shows that all the variables were stationary at their first difference (i.e. 1(1)). The result of the table also confirms that the variables were co-integrated in the longrun at the same rate by the normalized co-integration coefficient with the highest log likelihood in absolute term.

Table 1: ADF Unit Root Test Result

\begin{tabular}{|c|c|c|c|c|c|c|}
\hline VARIABLES & $\begin{array}{l}\text { ADF } \\
\text { SATS }\end{array}$ & $\begin{array}{l}\text { CRITICAL } \\
\text { VALUE } \\
1 \%\end{array}$ & $\begin{array}{l}\text { CRITICAL } \\
\text { VALUE } \\
5 \%\end{array}$ & $\begin{array}{l}\text { CRITICAL } \\
\text { VALUE } \\
10 \%\end{array}$ & $\begin{array}{l}\text { ORDER OF } \\
\text { INTEGRATIO } \\
\mathrm{N}\end{array}$ & REMARK \\
\hline EXPORT & -5.308594 & -3.632900 & -2.948404 & -2.612874 & $1(1)$ & stationary \\
\hline BUDGET & -5.550498 & -3.639407 & -2.951125 & -2.614300 & 1(1) & stationary \\
\hline $\mathrm{GDP}_{\text {AGRIC }}$ & -6.192236 & -3.639407 & -2.951125 & -2.614300 & 1(1) & stationary \\
\hline NPC & -5.890904 & -3.639407 & -2.951125 & -2.614300 & 1(1) & stationary \\
\hline SSR & -3.657007 & -3.657007 & -2.967767 & -2.622989 & 1(1) & stationary \\
\hline TM & -6.692878 & -3.632900 & -2.948404 & -2.612874 & 1(1) & stationary \\
\hline FDI & -11.91513 & -3.639407 & -2.951125 & -2.614300 & 1(1) & stationary \\
\hline
\end{tabular}

Source: computed output with e-view

Table 2: Johansen Cointegration Test Result

\begin{tabular}{|c|c|c|c|}
\hline $\begin{array}{l}\text { EIGEN } \\
\text { VALUE }\end{array}$ & $\begin{array}{l}\text { LIKELIHOOD RATIO } \\
\text { (LR) }\end{array}$ & $\begin{array}{l}\text { CRITICAL } \\
\text { VALUE } \\
5 \%\end{array}$ & $\begin{array}{l}\text { HYPOTHESIZE } \\
\text { D NO OF C.E }\end{array}$ \\
\hline 0.734822 & - & 46.23142 & None** \\
\hline 0.673258 & 1464.734 & 40.07757 & At most 1 \\
\hline 0.581074 & 1446.277 & 33.87687 & At most 2 \\
\hline 0.5410732 & 1431.921 & 25.58434 & At most $3^{* *}$ \\
\hline 0.458023 & 1419.082 & 21.13162 & At most $4 * *$ \\
\hline 0.363664 & 1408.976 & 14.26460 & At most $5^{*}$ \\
\hline 0.090478 & 1401.517 & 3.841466 & At most $6 * *$ \\
\hline
\end{tabular}

$*(* *)$ denotes rejection of the hypothesis at 5 percent (1 percent) significance levels. L.R. test indicates 5 cointegration equations ( $s$ ) at 5 percent level. C.E represents Co-integrating Equations

Source: computed output with e-view

\subsection{Estimates of Agricultural Protection Coefficient in Nigeria}

The level of protection in the agricultural sector in Nigeria (Table 3) shows an unsteady trend with mean value of $1.4 \%$, minimum of $-7.1 \%$ and maximum of $9.8 \%$. This suggests that Nigeria protects agricultural sector. This result is in line with previous studies (Olper, 1998) which states that the patterns of agricultural policies in Africa suggest that developing nations strongly subsidize or protect agriculture. This concept aimed at measuring the level of price 
protection or intervention using the nominal rate of protection (NRP) or the nominal protection coefficient (NPC). A coefficient of 1.10 implies that farmers, overall, received prices that were $10 \%$ above international market levels. This indicators as contained in figures 1and 2 reflect the level of price distortions across selected commodities which were measured using the Producer Nominal Protection Coefficient (NPC) and nominal protection rate (NPR) expressed as the ratio of farm price to border reference price.

Table3: Computations Showing Nominal Protection Coefficient of Agricultural Protection in Nigeria from, 1980 - 2016

\begin{tabular}{|c|c|c|c|c|c|c|c|}
\hline YEAR & NPC maize & NPC p-oil & $\begin{array}{r}\text { NPC } \\
\text { rice } \\
\end{array}$ & $\begin{array}{r}\text { NPC } \\
\text { rubber }\end{array}$ & NPC wheat & $\begin{array}{r}\text { AVERAGE } \\
\text { NPC }\end{array}$ & $\begin{array}{l}\text { NPR } \\
(\%)\end{array}$ \\
\hline 1980 & 0.6 & 0.9 & 1.1 & 1.1 & 1.0 & 0.93 & -7.1 \\
\hline 1981 & 0.6 & 1.0 & 1.1 & 1.1 & 1.0 & 0.95 & -5.3 \\
\hline 1982 & 0.7 & 1.0 & 1.1 & 1.1 & 1.0 & 0.98 & -2.3 \\
\hline 1983 & 0.6 & 1.0 & 1.1 & 1.1 & 1.0 & 0.94 & -5.5 \\
\hline 1984 & 0.6 & 1.0 & 1.1 & 1.1 & 1.0 & 0.95 & -5.5 \\
\hline 1985 & 0.8 & 0.9 & 1.1 & 1.1 & 1.0 & 0.96 & -3.5 \\
\hline 1986 & 0.9 & 1.0 & 1.1 & 1.1 & 1.0 & 1.01 & 0.7 \\
\hline 1987 & 1.0 & 1.0 & 1.1 & 1.0 & 1.0 & 1.02 & 2.3 \\
\hline 1988 & 1.0 & 1.0 & 1.1 & 1.0 & 1.0 & 1.02 & 1.8 \\
\hline 1989 & 1.0 & 1.0 & 1.1 & 1.0 & 1.0 & 1.01 & 0.7 \\
\hline 1990 & 1.0 & 1.0 & 1.1 & 1.0 & 1.0 & 1.02 & 1.6 \\
\hline 1991 & 1.0 & 1.0 & 1.1 & 1.1 & 1.0 & 1.03 & 2.7 \\
\hline 1992 & 1.0 & 1.0 & 1.1 & 1.1 & 1.0 & 1.03 & 2.9 \\
\hline 1993 & 1.0 & 1.0 & 1.1 & 1.1 & 1.0 & 1.05 & 4.9 \\
\hline 1994 & 1.0 & 1.0 & 1.3 & 1.1 & 1.0 & 1.10 & 9.8 \\
\hline 1995 & 1.0 & 1.0 & 1.0 & 1.0 & 1.0 & 1.01 & 1.4 \\
\hline 1996 & 1.0 & 1.0 & 1.0 & 1.0 & 1.0 & 1.00 & -0.2 \\
\hline 1997 & 1.0 & 1.0 & 1.0 & 1.1 & 1.0 & 1.02 & 1.9 \\
\hline 1998 & 1.0 & 1.0 & 1.0 & 1.1 & 1.0 & 1.02 & 2.3 \\
\hline 1999 & 1.0 & 1.0 & 1.0 & 1.1 & 1.0 & 1.04 & 3.6 \\
\hline 2000 & 1.0 & 1.0 & 1.0 & 1.1 & 1.0 & 1.03 & 3.1 \\
\hline 2001 & 1.0 & 1.0 & 1.0 & 1.1 & 1.0 & 1.02 & 2.1 \\
\hline 2002 & 1.0 & 1.0 & 1.0 & 1.1 & 1.0 & 1.03 & 3.1 \\
\hline 2003 & 1.0 & 1.0 & 1.0 & 1.0 & 1.0 & 1.02 & 1.8 \\
\hline 2004 & 1.0 & 1.0 & 1.0 & 1.1 & 1.0 & 1.02 & 2.3 \\
\hline 2005 & 1.0 & 1.0 & 1.0 & 1.0 & 1.0 & 1.02 & 1.5 \\
\hline 2006 & 1.0 & 1.0 & 1.0 & 1.0 & 1.0 & 1.01 & 1.2 \\
\hline 2007 & 1.0 & 1.0 & 1.0 & 1.0 & 1.1 & 1.03 & 2.7 \\
\hline 2008 & 1.0 & 1.0 & 1.1 & 1.0 & 1.1 & 1.04 & 4.0 \\
\hline 2009 & 1.0 & 1.0 & 1.1 & 1.0 & 1.1 & 1.04 & 3.5 \\
\hline 2010 & 1.0 & 1.0 & 1.1 & 1.0 & 1.1 & 1.04 & 3.6 \\
\hline 2011 & 1.0 & 1.0 & 1.0 & 1.0 & 1.0 & 1.01 & 1.1 \\
\hline 2012 & 1.0 & 1.0 & 1.0 & 1.0 & 1.0 & 1.02 & 2.0 \\
\hline
\end{tabular}




\begin{tabular}{rrrrrrrr}
\hline 2013 & 1.0 & 1.0 & 1.0 & 1.0 & 1.0 & 1.01 & 1.2 \\
2014 & 1.1 & 1.0 & 1.0 & 1.0 & 1.1 & 1.03 & 2.8 \\
2015 & 1.0 & 1.0 & 1.0 & 1.0 & 1.1 & 1.04 & 3.6 \\
2016 & 1.1 & 1.0 & 1.0 & 1.0 & 1.2 & 1.01 & 3.4 \\
\hline Min & & & & & & 0.93 & $-7.1 \%$ \\
Max & & & & & & 1.10 & $9.8 \%$ \\
Mean & & & & & & 1.01 & $1.4 \%$ \\
\hline
\end{tabular}

Nominal rate of protection (NRP) is also given as (NPC-1) x100 in percentages.

Source: Author's Computation, 2018.

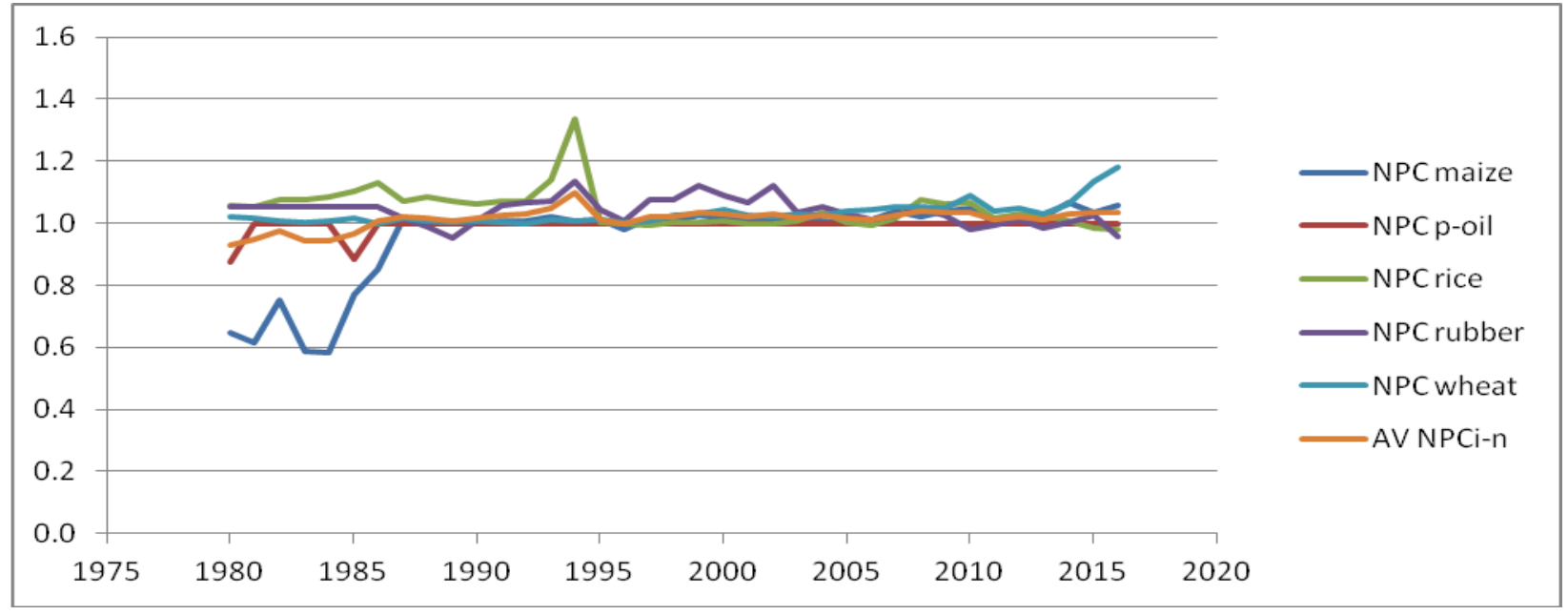

Figure 1: Graphical Representation of Nominal Protection Coefficient (Agricultural Protection) of selected agricultural commodities in Nigeria from $1980-2016$

Source: Author's Computation, 2018.

\section{NPR}

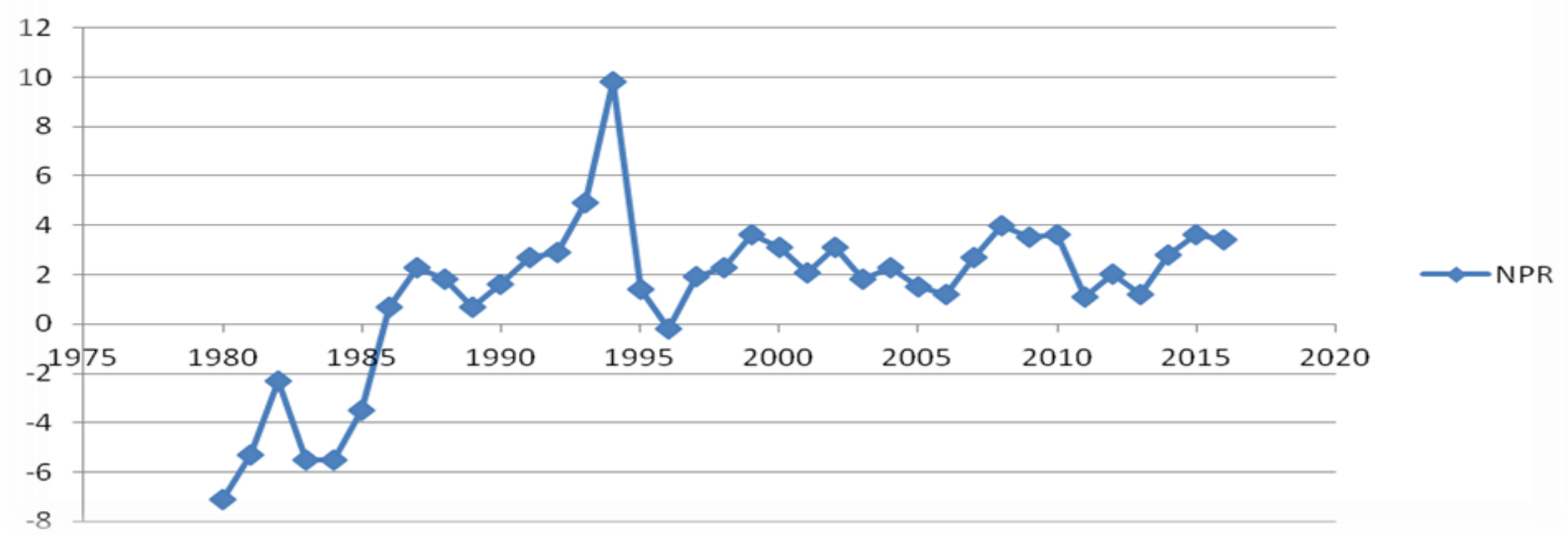

Figure 2: Graphical Representation of Nominal Protection Rate in Nigeria from 1980 - 2016 Source: Author's Computation, 2018 


\subsection{Estimates domestic food supply in Nigeria}

The ability to produce own food and reduce dependency on importation has been one of the major policy objectives among many African countries. Nigeria's food self-sufficiency ratio on major staple foods in Nigeria from 1980 to 2016 was calculated and the average presented in Table 4 and Figure 3. The results show that apart from the period between 1987 and 1991 when the SSR was highest, ranging from 70.8 to 84.8 percent, the rest of the period was characterized by huge dependency on food importation and lesser food sufficiency ratio. The result also shows that from 1999 to 2016, which represents the period under Nigeria's democratic rule, the NPC has stayed steadily between $54.5 \%-62.2 \%$ showing that no meaningful increase has taken place since this democratic regime.

Table 4: Table presentation of average estimate of food self sufficiency ratio (SSR) in Nigeria between 1980 and 2016

\begin{tabular}{rrrrrrrr}
\hline YEAR & SSR & YEAR & SSR & YEAR & SSR & YEAR & SSR \\
\hline 1980 & 50.5 & 1990 & 84.8 & 2000 & 61.5 & 2010 & 57.7 \\
1981 & 47.2 & 1991 & 70.8 & 2001 & 54.5 & 2011 & 57.2 \\
1982 & 46.9 & 1992 & 67.4 & 2002 & 57.7 & 2012 & 57.1 \\
1983 & 56.2 & 1993 & 64.2 & 2003 & 56.3 & 2013 & 56.9 \\
1984 & 58.5 & 1994 & 64.2 & 2004 & 57.6 & 2014 & 57.0 \\
1985 & 61.1 & 1995 & 65.9 & 2005 & 58.9 & 2015 & 57.1 \\
1986 & 64.3 & 1996 & 65.2 & 2006 & 60.9 & 2016 & 56.8 \\
1987 & 78.4 & 1997 & 62.8 & 2007 & 58.0 & & \\
1988 & 71.5 & 1998 & 63.8 & 2008 & 61.0 & & \\
1989 & 73.0 & 1999 & 62.2 & 2009 & 59.1 & & \\
\hline
\end{tabular}

This average estimate of food self sufficiency ratio (SSR) was calculated using the SSR of major staple foods in Nigeria. Source: Author's Computation, 2018

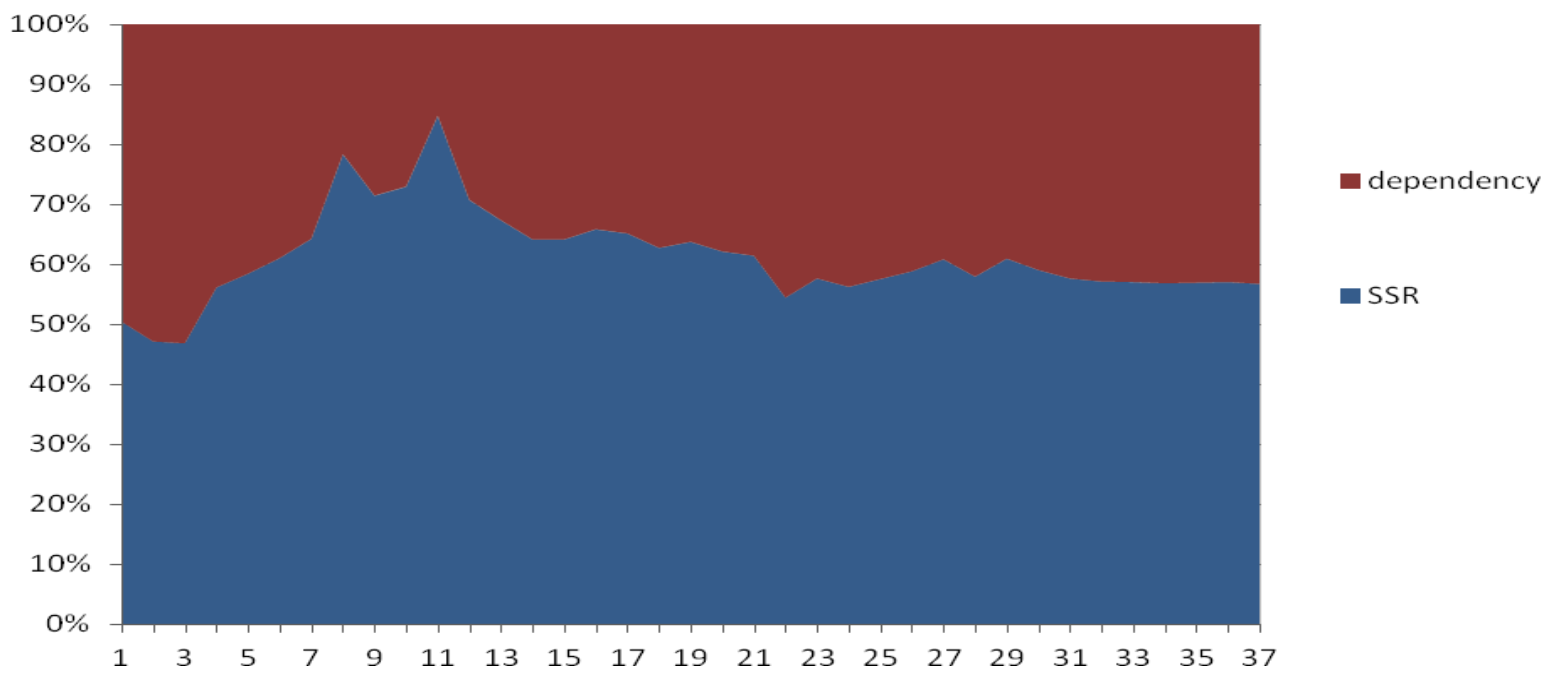

Figure 3: Graphical Area Representation of food SSR from 1980 - 2016.

Source: Author's Computation, 2018. 


\subsection{Estimates of farmer welfare in Nigeria}

The proxy for measuring the price distortion advantage in financial values as accrued to Nigerian farmers in Table 5 and Figure 4 shows that the most favourable period for farmers was between 2010 and 2012 when Growth-Based Agricultural Policy, Agricultural Transformation Agenda and Growth Enhancement Support (GES) schemes were executed. From the table 5 and figure 4, the results show that the welfare package to farmers were merely staggering between 1980 and 2009. This suggests that the policies have not been very favourable to farmers when compared to international prices. In line with expectations, Harberger (1959) had opined that there is overwhelming empirical evidence suggesting a strong link between price distortions and economic growth, especially in developing countries. During this period too, average GDP share to the sector was 25.3 percent and above the mean value of 21 percent. Also, in line with results from global and single country studies of subsidy reform suggest that on an aggregate level, changes to GDP are likely to be positive due to the incentives resulting from price changes leading to more efficient resource allocation (Von Moltke, Mckee, \& Morgan, 2004). Therefore, GDP share from agriculture could be used to check if efficient resources were allocated to appropriate policies in a particular place and time.

Table 5: Table presentation of farmers' economic welfare in Naira between 1980 and 2016

\begin{tabular}{rrrrrrrr}
\hline YEAR & AV TM & YEAR & AV TM & YEAR & AV TM & YEAR & AV TM \\
\hline 1980 & 60686281 & 1990 & 145833703 & 2000 & 161373522 & 2010 & 242727700 \\
1981 & 75046349 & 1991 & 163540719 & 2001 & 114436819 & 2011 & 344972298 \\
1982 & 57469514 & 1992 & 134441975 & 2002 & 64915892 & 2012 & 174308887 \\
1983 & 46761825 & 1993 & 118367860 & 2003 & 150367319 & 2013 & 148967140 \\
1984 & 35386468 & 1994 & 180348350 & 2004 & 146206977 & 2014 & 110192896 \\
1985 & 24983884 & 1995 & 156189188 & 2005 & 140515254 & 2015 & 18721698 \\
1986 & 23813465 & 1996 & 178140863 & 2006 & 156739490 & 2016 & 31910376 \\
1987 & 57217767 & 1997 & 155126058 & 2007 & 122805774 & & \\
1988 & 93590225 & 1998 & 153492256 & 2008 & 150913174 & & \\
1989 & 123421022 & 1999 & 94136451 & 2009 & 82122932 & & \\
\hline
\end{tabular}

AVTM is the Average Trade Measures in Naira accrued to farmers in Nigeria.

Source: Author's Computation, 2018

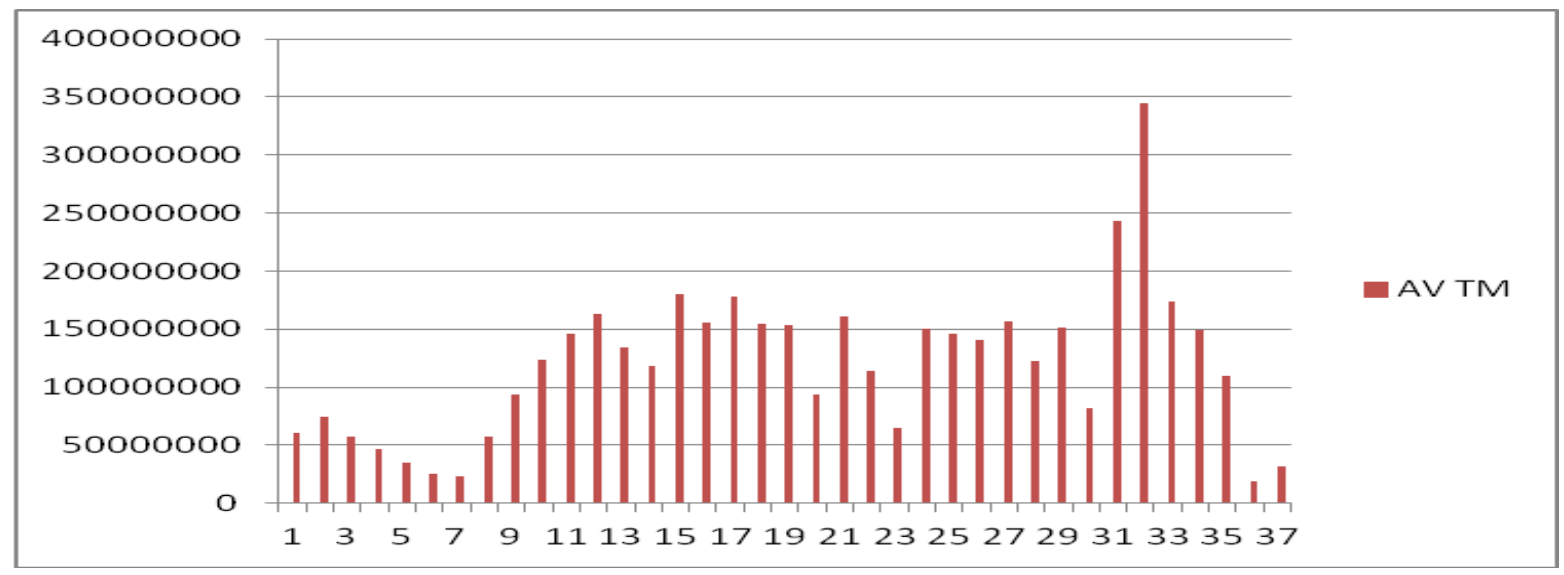

Figure 4: Graphical charts of FARMER-WELFARE in Nigeria from 1980 - 2016. Note: 1to 37 represent 1980 to 2016; AVTM represents Average Trade Measures.

Source: Author's Computation, 2018 
4.4 Effectiveness of Agricultural Protection on Agricultural Food Self Supply, Agricultural Export, and FarmerWelfare.

The result of the regression analysis of the effects of agricultural protection and other political economy variables on growth outputs i.e, Y1, Y2, and Y3 in the model are shown in Table 6. The variables were first tested of endogeneity. Knowing that if the $\mathrm{p}<0.5$, accept the null hypothesis that the model contains endogenous variables or reject it if otherwise. From the result, the probability was lesser than $0.05(0.0003)$. Therefore, the variables are endogenous and fit for instrumental variable GMM regression. The regression output as analysed with GMM is presented in Table 6 and each dependent variable is discussed under the following sub-headings:

\subsubsection{Domestic Food Supply (SSR)}

From the table, about $83 \%$ variations in agricultural exports were explained by variations in the political economy variables which was statistically significant $(\mathrm{p}<0.01)$. This means that at least, one or more variables specified in the model significantly affected the export growth from agricultural sector. From this result in table 4.7, the null hypothesis which states that agricultural protection policy does not have significant effect on agricultural export in Nigeria be rejected. The effect of agricultural protection on agricultural export was negative and significant $(p<0.001)$. Therefore, a unit increase in the predictor variable showed that the outcome of agricultural export decreased by $0.07 \%$. This means that in the long run, as protection increased, export from the sector declined significantly. The effect of structural changes in policy outlook was negative and significant $(\mathrm{p}<0.001)$ on agricultural export level. Statistically, when the political/policy structure outlook appeared to favour liberalization, the outcome of export decreased by $0.48 \%$. The structural outlook content is another determinant in decision making processes. On one part, it forms a basis for level of demand or pressure from the farmers and on the second hand, the level of response or supply of protection instruments by the government. According to Virender (1993), the structural changes that occur during the course of economic development have been shown as instrumental in bringing about a switch in export considerations. This means that negative coefficient of POCH i.e., liberalization favours export more than protection. The effect of CPI on GDP share from agricultural sector was positive and significant $(\mathrm{p}<0.001)$. In other words, a unit increase in predictor variable showed that the outcome of export increased by $0.01 \%$. This is in line with the apriori expectation that increase in price would lead to increase in production thereby increasing the export from the sector.

\subsubsection{Agricultural Export}

The result shows that about $83 \%$ variations in agricultural exports were explained by variations in the political economy variables which was statistically significant $(\mathrm{p}<0.01)$. This means that at least, one or more variables specified in the model significantly affected the export growth from agricultural sector. From this result in table 6, the null hypothesis which states that agricultural protection policy does not have significant effect on agricultural export in Nigeria be rejected. This is because NPR is significant in the regression. The effect of agricultural protection on agricultural export was negative and significant $(\mathrm{p}<0.001)$. Therefore, a unit increase in the predictor variable showed that the outcome of agricultural export decreased by $0.07 \%$.

Table 6: Parameter estimates of GMM regression on effectiveness of agricultural protection and other political economy variables on Nigeria's self-sufficiency ratio, agricultural export and FARMER-WELFARE.

\begin{tabular}{lllr}
\hline Variables & Parameters & Standard Error & T-ratio \\
\hline Y1=Self Sufficiency Ratio & & & \\
Constant & 57.13534 & 9.407739 & $6.073227^{* * *}$ \\
LnNPR & 0.695291 & 0.452162 & 1.537702 \\
LnFDIAGR & -0.910298 & 2.203268 & -0.413158 \\
$\ln \mathrm{TM}$ & 2.164594 & 1.917257 & 1.129006
\end{tabular}




\begin{tabular}{|c|c|c|c|}
\hline $\operatorname{LnPOCH}$ & -6.232640 & 4.787480 & -1.301862 \\
\hline $\begin{array}{l}L n \mathrm{CPI} \\
\mathrm{Y} 2=\text { Agric Export }\end{array}$ & 0.049667 & 0.028094 & $1.767856^{*}$ \\
\hline Constant & 6.869506 & 0.374818 & $18.32759^{* * *}$ \\
\hline $\ln \mathrm{NPR}$ & -0.059485 & 0.015828 & $-3.758097 * * *$ \\
\hline $\ln$ FDIAGR & -0.066068 & 0.032830 & -2.012452 \\
\hline ln BUDAGR & 0.004435 & 0.016790 & 0.264168 \\
\hline $\ln \mathrm{TM}$ & -0.032595 & 0.082989 & -0.392769 \\
\hline $\ln \mathrm{POCH}$ & -0.489985 & 0.071195 & $-6.882311 * * *$ \\
\hline $\ln \mathrm{CPI}$ & 0.008697 & 0.001220 & $7.127612 * * *$ \\
\hline $\begin{array}{l}\text { In GDPAGR } \\
\mathrm{Y} 3=\text { Farmer-Welfare }\end{array}$ & -0.006024 & 0.006732 & -0.894832 \\
\hline Constant & 5.816706 & 3.002052 & $1.937577 * * *$ \\
\hline LnGOTYPE & -0.297168 & 0.284175 & -1.045722 \\
\hline LnPOCH & 0.669714 & 0.247875 & $2.701821 * *$ \\
\hline LnBUDAGR & -0.015157 & 0.038023 & -0.398618 \\
\hline $\operatorname{LnCPI}$ & 0.005888 & 0.008609 & 0.683886 \\
\hline LnEXR & -0.000457 & 0.004718 & -0.096883 \\
\hline LnAGREXP & -0.265387 & 0.461839 & -0.574631 \\
\hline LnNPR & 0.066129 & 0.032906 & $2.009644 *$ \\
\hline
\end{tabular}

Key: $* * *, * * *$ - represent $1 \%, 5 \%$ and $10 \%$ levels of significance respectively

$Y 1: R^{2}-31 \%$, instrument specification: Incpi2, lngdpagr, lnnpr, Infdiagr, Inbudagr, Intm, lnagrexp, In poch. constant added to instrument

Y2: $R^{2}-83 \%$. IV specification: Ingdpagr, Innpr, Infdiag, Inbudagr, Intm, Inagrexp, In poch,constant added to instrument

Y3: $R^{2}-54 \%$. Instrument specification: Intm, Ingotype, Inbudsgr, Incpi(2), Inexr, Inagrexp, Innpr, constant added to instrument

Source: Author's computation from Eviews 9.0, 2018.

This means that in the long run, as protection increased, export from the sector declined significantly. The effect of structural changes in policy outlook was negative and significant $(\mathrm{p}<0.001)$ on agricultural export level. Statistically, when the political/policy structure outlook appeared to favour liberalization, the outcome of export decreased by $0.48 \%$. The structural outlook content is another determinant in decision making processes. On one part, it forms a basis for level of demand or pressure from the farmers and on the second hand, the level of response or supply of protection instruments by the government. According to Virender (1993), the structural changes that occur during the course of economic development have been shown as instrumental in bringing about a switch in export considerations. This means that negative coefficient of POCH i.e., liberalization favours export more than protection. The effect of CPI on GDP share from agricultural sector was positive and significant ( $<0.001)$. In other words, a unit increase in predictor variable showed that the outcome of export increased by $0.01 \%$. This is in line with the apriori expectation that increase in price would lead to increase in production thereby increasing the export from the sector.

\subsubsection{Farmer-Welfare}

The result shows that about 54\% variations of the economic welfare accrued to agricultural producers were explained by variations in NPR and other political economy variables in the model. From this result in Table 4.8, 
the null hypothesis which states that agricultural protection does not have significant effect on farmers' economic welfare in Nigeria was rejected. The specified political economy variables that had significant effects on their economic welfare in Nigeria were policy structural changes $(\mathrm{POCH})$ and level of agricultural protection (NPR). The policy structure outlook in the sector was vectorized into protection (+) and non-protection (-) eras. The effect of POCH on farmers' economic welfare was negative and significant $(\mathrm{p}<0.05)$. In other words, a change from protection structure to liberalisation showed that the farmers' economic welfare also increased by $0.69 \%$. This is often the situation because many of the investors in the sector consider the nature and structure of the policy on ground before increasing or reducing their capital shares. The effect of agricultural protection on FARMERWELFARE was positive and significant $(\mathrm{p}<0.05)$. Therefore, a unit increase in the predictor variable showed that the outcome of famer welfare increased by $0.07 \%$. This means that in the long run, as protection increased, gains made by farmers increased significantly.

\section{Conclusions/Recommendations}

The average level of agricultural protection in Nigeria was poor between 1980 and 1985 but became significantly pronounced afterward and varies across food commodities and time. Protection is not without cost implications on the supply side (government) but these expenditures seem not to be commensurate with the results of the expected outcomes of the protection policy especially on domestic food production, and agricultural export. This study showed that the level of protection policy promulgated in the country during these periods under study only affected level of export and economic advantage received by the local farmers. However, the policy did not affect the measure of domestic food supply significantly.

This study, therefore, recommends among others that these forms of agricultural protection policies be reformed to ensure that policies motivate the production of staple food for the domestic consumption. This will reduce the nation's dependence on importation. To do this, stakeholders are expected to hold conferences on how a new and all-inclusive protection policy could be promulgated to motivate the sector out of stagnation and subsistence farming.

\section{References}

ABOU, N., \& TAKOR, W. (1999). Tax incentives in Lebanon. A Paper Presented at the United Nations Conference on Trade and Development (UNCTAD) at the Expert Meeting on Tax Incentives; 7-8.

AKANEGBU, B.N. (2015). Agricultural price distortions and their effects on the Nigerian economy: An Empirical Analysis. European Journal of Research in Social Sciences. 3 (1). ISSN $2056-5429$

AMIN, S. (1972). Underdevelopment and dependence in black Africa: Origins and contemporary forms. Journal of Modern African Studies, 10(4), 503-24.

ARENE C.J. (2008 ${ }^{\text {b }}$. Agricultural Economics: a functional approach. Prize Publishers, Enugu Nigeria.

AYOOLA, G.B., AINA, B.M., NWEZE, N., ODEBIYI, T., OKUNMADEWA, F., SHEHU D., WILLIAM O. \& ZASHA, J. (2000). Nigeria: Voice of the Poor, Country Synthesis Report, World Bank.

BALDWIN, ROBERT, (1982). The Political Economy of Protectionism: In Import Competition and Response, ed. Jagdish N. Bhagwati. Chicago: University of Chicago Press.

BARETTE, C.B. (1999). Micro-economics of the development paradox on the political economy of food price policy. Agricultural Economics 20(1999) 159-172.

BEGHIN, J.C \& M. KHERALLAH (1994), "Political Institutions and International Patterns of Agricultural Protection", Review of Economics and Statistics 76(3): 482-489.

BEGHIN, J.C \& M. KHERALLAH (1994), "Political Institutions and International Patterns of Agricultural Protection", Review of Economics and Statistics 76(3): 482-489. 
BRIGGS, I.N. (2005). Nigeria: protecting domestic production in terms of liberalization and the short, medium and long term implication for regional integration. A paper presented at the ECOWAS Regional workshop on Multilateral Trade Agreements, parliament of Ghana and Friedrich-Ebert-Stiftung, Accra, Ghana, November 27, 2005.

CIA WORLD FACTBOOK (2015). The World Factbook. Retrieved November 26, 2015, from www.cia.gov

COOPER, F. (2002). Africa since 1940: The Past of the Present. Cambridge.

DE GORTER, H. \& TSUR, Y. (1991). Explaining price bias in world agriculture: The calculus of support maximizing politicians. American Journal of Agricultural Economics, 73,1244-54.

DE MELO, J.A.P. (1978). Protection and resources allocation in walrasian trade model. International Economic Review, 19, 25-43.

FAO. (2012). Foreign Agriculture Investment Profile - Nigeria. Food and Agriculture Organization (FAO) Investment Policy Support. Retrieved February 16, 2016, from http://www.fao.org/fileadmin/user_upload/tcsp/docs/Nigeria_Country_Profile_FINAL.pdf

GARDNER, B.L. (1987), “Causes of U.S. Farm Commodity Programs”, Journal of Political Economy 95(2), 290310.

GARDNER, L. (2012). Taxing colonial Africa: The political economy of British imperialism. (Oxford U. Press, 2012), Ch. 1, an Introduction to the Problem of Colonial Taxation. pp. 1-13.

GOLDIN, I. \& KNUDSEN, O. (ED). (1990). Agricultural Trade Liberalization: Implication for developing countries. Paris OECD and World Bank.

GOMES, G.M. (1999). State level tax incentives in Brazil. A Paper presented at the expert meeting on tax incentives; pp 8-9.

GRAIS, W., DE MELO, J., \& URATA, S. (1986). A general equilibrium estimation of the reduction of tariffs and quantitative restrictions in Turkey in 1978. In Thirukodikaval Srinivasan, John Whalley, (Eds.), General equilibrium trade policy modeling. Cambridge, MA.

HARBERGER, A.C. (1959). The fundamentals of economic progress in underdeveloped countries: Using the resources at hand more efficiently. American Economic Review, 49, 134-146.

HOLLAND, M. (1996). Income tax incentives for investment. A Ph.D Dissertation Submitted to the Department of Economics and Finance, National University of Singapore.

HONMA, M. \& HAYAMI, Y. (1986). Structure of agricultural protection in industrial countries. Journal of International Economics, 20, 115-129.

IKPI, A.E (1989). Understanding the rural farmers for effective adoption of improved agricultural technology and impact modelling, IITA, Research Monograph No4, Ibadan, Nigeria.

INHWAM, J. (2008). Determinants of Agricultural Protection in Industrial Countries. An Empirical Bulletin, 17 (1), $1-11$.

International Food and Agricultural Development (IFAD). (2016). Poverty in Rural Nigeria. www.ruralpovertyportal.org/country/home/tags/nigeria/IFAD

JOACHIM, Z. \& VALDES, A. (1993). Growth of Agricultural Protection. Trade and Protectionism, NBER-EASE Volume 2, University of Chicago Press ISBN: 0-226-38668-6. Accessed from URL: http://www.nber.org/chapters/c8073

JOSLING, T. (1975). The world food problem. Food Policy, 1 (1), 3-14. 
JOSLING, T. E. \& VALDES, A. (2004). Agricultural Policy Indicators. ESA Working Paper No. 04-04. Agricultural and Development Economics Division. The Food and Agriculture Organization (FAO) of the United Nations.

KIABEL, B.D. \& NWIKPASI, N.N. (2001). Selected aspect of Nigerian taxes. Owerri; Springfield Publishers

KRUEGER, A. O. (1992). The Political Economy of Agricultural Pricing Policies: Volume 5: A Synthesis of the Political Economy in Developing Countries. A World Bank Comparative Study, Baltimore, MD: John Hopkins University Press for the World Bank.

KRUEGER, A.O. (1978). Liberalization attempts and consequences. New York: National European Journal of Research in Social Sciences Vol. 3 No. 1, 2015 ISSN 2056-5429 Progressive Academic Publishing, UK Page 98 www.idpublications.org Bureau for Economic Research.

KRUEGER, A.O., M. SCHIFF \& VALDES, A. (1988). Agricultural Incentives in Developing Countries: Measuring the Effects of Sectoral and Economy-wide Policies, World Bank Economic Review 2(3), 255-72, September.

National Bureau of Statistics [NBS], (2017). National population figures. Retrieved November 22, 2017, from http://www.nigerianstat.gov.ng

NJOKU,C.O., CHIGBU, E.E. \& AKUJUOBI, A.B.C. (2015). Public Expenditure and Economic Growth in Nigeria (A Granger Causality Approach) 1983-2012. Management Studies and Economic Systems (MSES), 1 (3), 147-160, Winter 2015.

OECD (2018). Producer protection (indicator). doi: 10.1787/f99067c0-en (Accessed on 04 October 2018).

OGHOGHOMEH, T. (2014). An assessment of agribusiness tax incentives in Nigeria. international journal of business and economic development Vol. 2 Number 1 March 2014. www.ijbed.org

OKUMADEWA, F. (1997). Poverty and income in Nigeria: Measurements and Strategies for reform: A Paper Presented at the Vision 2010 Workshop, Abuja.

OLATOMIDE W.O. \& OMOWUMI A.O. (2013). Policy interventions and public expenditure reform for pro-poor agricultural development in Nigeria. African Journal of Agricultural Research. Vol. 9(4), pp. 487-500, (http://www.academicjournals.org/AJAR).

OLAWEPO R. A. (2010). Determining rural farmers' income: A rural Nigeria experience. Journal of African Studies and Development, 2(4), 99-108.

OLPER, A. (1998). Political Economy Determinants of agricultural protection levels in EU Member States: an empirical investigation. Eoropean Review of Agricultural Economics, 25,463-487.

OWUTUAMOR, Z.B. AND ARENE, C.J. (2018). The impact of foreign direct investment on agricultural growth in Nigeria (1979-2014). Review of Agricultural and Applied Economics. The Successor of the Acta Oeconomica et Informatica, ISSN 1336-9261, XXI (Number 1, 2018): 40-54 doi: 10.15414/raae/2018.21.01.40-54

PEJOUT, N. (2010). Agriculture policy in Africa-renewal or status quo? A spotlight on Kenya and Senegal. The political economy of Africa. V. Padayachee, London, Abingdon: 247-265.

PHILIP, D. (1995). Corporate tax incentives and economic growth in Nigeria. Nigeria Tax News; 2(1) April; pp 163.

POULTON, C., EDWARD, A. \& KYDD, J. (2005). The Future of small farmers: New direction for services, institutions and intermediations. In proceedings of research workshop on the future of small farms, Wye, UK. Organized by International Food policy Research Institute (ODI), Imperial College, London.

SWINNEN, J. (1996). Endogenous price and trade policy developments in central European Agriculture. Euro Rev. Agric. Econ. 23(2), 133-166. 
SWINNEN, J. F. M. \&. VAN DER ZEE, F. A. (1993). The political economy of agricultural policies: A survey. European Review of Agricultural Economics, 20, 261-290.

THIES, C.G., \& PORCHE S. (2007), “The Political Economy of Agricultural Protection”, Journal of Politics 69(1),116-127.

TIMMER, C.P. (1980). Food prices and food policy analysis in LDCs. Food Policy, 5, 188-199.

VAN DE WALLE, N. (1999). African economies and the politics of permanent crisis, 1979 Cambridge: Cambridge University Press, 2001.

VIRENDER, G. (1993). The political economy of international Agricultural Protection. Retrospective Theses and Dissertations, Iowa State University.

VON MOLTKE, A., MCKEE, C. \& MORGAN, T. (2004). Energy Subsidies: Lessons Learned in assessing their impact and designing policy reforms. Sheffield: Greenleaf Publishing.

ZIETZ, J. \& VALDES, A. (1993). Growth of agricultural protection, trade and protectionism. NBER-EASE Volume 2, University of Chicago Pres ISBN: 0-226-38668-6. Accessed 25/03/2017 from URL: http://www.nber.org/chapters/c8073.

\section{Appendixes}

BUDGETARY ALLOCATION FOR AGRICULTURE IN NIGERIA, 1980-2016

\begin{tabular}{|c|c|c|c|c|}
\hline Years & All Sectors & Agric & $\begin{array}{l}\text { Total } \\
\%\end{array}$ & Agric \% \\
\hline 1980 & NA & NA & 100 & NA \\
\hline 1981 & 7965.9 & 141.9 & 100 & 1.8 \\
\hline 1982 & 10277.9 & 127.3 & 100 & 1.2 \\
\hline 1983 & 10684.3 & 166.2 & 100 & 1.6 \\
\hline 1984 & 11827.8 & 167.0 & 100 & 1.4 \\
\hline 1985 & 12628.6 & 166.1 & 100 & 1.3 \\
\hline 1986 & 12628.6 & 150.8 & 100 & 1.2 \\
\hline 1987 & 14318.7 & 139.9 & 100 & 1.0 \\
\hline 1988 & 15751.1 & 221.1 & 100 & 1.4 \\
\hline 1989 & 20080.9 & 263.5 & 100 & 1.3 \\
\hline 1990 & 22070.7 & 443.7 & 100 & 2.0 \\
\hline 1991 & 35282.7 & 494.0 & 100 & 1.4 \\
\hline 1992 & 54109.7 & 698.9 & 100 & 1.3 \\
\hline 1993 & 119460.3 & 1824.0 & 100 & 1.5 \\
\hline 1994 & 135824.4 & 1805.4 & 100 & 1.3 \\
\hline 1995 & 333019.2 & 1807.7 & 100 & 0.5 \\
\hline 1996 & 403947.7 & 1807.7 & 100 & 0.4 \\
\hline 1997 & 419864.7 & 1819.9 & 100 & 0.4 \\
\hline
\end{tabular}




\begin{tabular}{|r|r|r|r|r|}
\hline 1998 & 445238.1 & 1904.0 & 100 & 0.4 \\
\hline 1999 & 444956.4 & 1904.0 & 100 & 0.4 \\
\hline 2000 & 416237.0 & 1907.8 & 100 & 0.5 \\
\hline 2001 & 461083.5 & 1910.8 & 100 & 0.4 \\
\hline 2002 & 469958.6 & 1913.9 & 100 & 0.4 \\
\hline 2003 & 499839.9 & 1913.9 & 100 & 0.4 \\
\hline 2004 & 636865.4 & 1913.9 & 100 & 0.3 \\
\hline 2005 & 698089.1 & 1913.9 & 100 & 0.3 \\
\hline 2006 & 896847.8 & 2553.5 & 100 & 0.3 \\
\hline 2007 & 1077318.4 & 33824.4 & 100 & 3.1 \\
\hline 2008 & 1400333.6 & 3171.8 & 100 & 0.2 \\
\hline 2009 & 878103.1 & 11217.9 & 100 & 1.3 \\
\hline 2010 & 891142.2 & 1588.9 & 100 & 0.2 \\
\hline 2011 & 1470098.4 & 6815.5 & 100 & 0.5 \\
\hline 2012 & 2616996.6 & 14219.7 & 100 & 0.5 \\
\hline 2013 & 3520246.8 & 13756.8 & 100 & 0.4 \\
\hline 2014 & 6461139.1 & 3943.5 & 100 & 0.1 \\
\hline
\end{tabular}

Source: CBN, 2018.

Years with NA were extrapolated.

NIGERIA'S GROSS DOMESTIC PRODUCT (GDP) 1980-2016

\begin{tabular}{|c|r|r|r|r|l|}
\hline Year & Agric (Total) & Agric $\%$ & \multicolumn{1}{c|}{ Construction } & \multicolumn{1}{c|}{ Total GDP } & \% total \\
\hline 1981 & 17052 & 11.8 & 11038 & 144831 & 100 \\
\hline 1982 & 20126 & 13.0 & 9904 & 154978 & 100 \\
\hline 1983 & 23798 & 14.6 & 8980 & 163000 & 100 \\
\hline 1984 & 30365 & 17.8 & 7587 & 170378 & 100 \\
\hline 1985 & 34237 & 17.8 & 6098 & 192273 & 100 \\
\hline 1986 & 35703 & 17.6 & 7643 & 202436 & 100 \\
\hline 1987 & 50287 & 20.2 & 8658 & 249439 & 100 \\
\hline 1988 & 73765 & 23.0 & 9820 & 320329 & 100 \\
\hline 1989 & 88264 & 21.1 & 15343 & 419196 & 100 \\
\hline 1990 & 106627 & 21.3 & 17318 & 499677 & 100 \\
\hline 1991 & 123236 & 20.7 & 19506 & 596045 & 100 \\
\hline 1992 & 184116 & 20.2 & 24320 & 909803 & 100 \\
\hline 1993 & 295325 & 23.5 & 31920 & 1259070 & 100 \\
\hline 1994 & 445273 & 25.3 & 41097 & 1762813 & 100 \\
\hline 1995 & 790142 & 27.3 & 54869 & 2895201 & 100 \\
\hline
\end{tabular}




\begin{tabular}{|l|r|r|r|r|l|}
\hline 1996 & 1070515 & 28.3 & 63856 & 3779133 & 100 \\
\hline 1997 & 1211462 & 29.5 & 74737 & 4111641 & 100 \\
\hline 1998 & 1341041 & 29.2 & 99027 & 4588990 & 100 \\
\hline 1999 & 1426974 & 26.9 & 109574 & 5307362 & 100 \\
\hline 2000 & 1508409 & 21.9 & 121819 & 6897482 & 100 \\
\hline 2001 & 2015422 & 24.8 & 162183 & 8134142 & 100 \\
\hline 2002 & 4251521 & 37.5 & 191007 & 11332253 & 100 \\
\hline 2003 & 4585926 & 34.5 & 234474 & 13301559 & 100 \\
\hline 2004 & 4935264 & 28.5 & 311850 & 17321295 & 100 \\
\hline 2005 & 6032332 & 27.1 & 414761 & 22269978 & 100 \\
\hline 2006 & 7513298 & 26.2 & 551632 & 28662469 & 100 \\
\hline 2007 & 8551981 & 25.9 & 733670 & 32995384 & 100 \\
\hline 2008 & 10100325 & 25.8 & 975781 & 39157884 & 100 \\
\hline 2009 & 11625442 & 26.3 & 1297789 & 44285561 & 100 \\
\hline 2010 & 13048893 & 23.9 & 1570973 & 54612264 & 100 \\
\hline 2011 & 14037826 & 22.3 & 1905575 & 62980397 & 100 \\
\hline 2012 & 15815998 & 22.1 & 2188719 & 71713935 & 100 \\
\hline 2013 & 16816553 & 21.0 & 2676284 & 80092563 & 100 \\
\hline 2014 & 18018613 & 20.2 & 3188823 & 89043615 & 100 \\
\hline $2015^{*}$ & 19636969 & 20.9 & 3472255 & 94144960 & 100 \\
\hline $2016^{*}$ & 21523513 & 21.2 & 3606560 & 101489492 & 100 \\
\hline
\end{tabular}

SOURCE: CBN, 2018

Years with asterisks were extrapolated

\section{Acknowledgement}

The authors acknowledge the useful comments from members of the Department of Agricultural Economics, University of Nigeria, Nsukka during the seminar sessions.

\section{Copyrights}

Copyright for this article is retained by the author(s), with first publication rights granted to the journal. This is an open-access article distributed under the terms and conditions of the Creative Commons Attribution license (http://creativecommons.org/licenses/by/4.0/). 